\title{
UN SEPULCRO PLATERESCO EN MÉXICO
}

Por Gonzalo Obregón.

UNA FELIZ casualidad y el examen cuidadoso de fuentes documentales me han permitido identificar, en forma segura, el monumento más importante que se hizo en México a fines del siglo xvi: el de don Alonso de Villaseca. Hagamos un poco de historia.

Don Alonso de Villaseca es una de las figuras más interesantes del siglo xvi. Era natural de Arcícola, pueblo de la diócesis de Toledo, hijo de don Andrés de Villaseca y de doña Teresa Gutiérrez de Toranzó, hidalgos y cristianos viejos. Pasó a la Nueva España hacia 1535, con las suficientes recomendaciones para poder casar, poco tiempo después, con doña Francisca Morón "hija única de padres tan poderosos, que de ellos se sabe tenían, entre otras, una hacienda de ganado mayor en que se herraban cada año veinte mil becerros..."1

Esta base económica, el cuidado que de ella tuvo y la suerte que lo acompañó, le permitieron aumentar su riqueza en tal forma que llegó a ser conocido como el hombre más rico de la Nueva España. Minas, haciendas ganaderas, tierras de labor, de todo tenía en su caudal.

A la llegada de los primeros jesuitas, en 1572, don Alonso, que era de carácter "seco y desapacible", empezó a hacerles limosnas de pocas cantidades al principio, teniéndolos en observación, hasta que, convencido de su desinterés y de la utilidad social que prestaban, abrió generoso sus arcas y no sólo les dio cuantiosas sumas, sino que se constituyó como fundador del Colegio Máximo de San Pedro y San Pablo, dando de inmediato cuarenta y seis mil pesos. Años más tarde, el nieto de don Alonso hacía cuenta de las donaciones de su abuelo, en total, cerca de doscientos treinta mil pesos, suma enorme para la época.

Cuando murió don Alonso de Villaseca, el 8 de septiembre de 1580 la Compañía de Jesús le hizo suntuosos funerales y numerosas misas fueron aplicadas por el descanso de su alma. Su cuerpo, embalsamado, fue depositado en la iglesia provisional que usaban los jesuitas mientras se construía la de San Pedro y San Pablo.

Una de las cláusulas de la escritura de fundación del Colegio estipu-

1 Pérez de Rivas, P. Andrés. Crónica de la Provincia de la Compañia de Jesús en México. Morelia. 1896, libro II, cap. Iv. 
laba que don Alonso tendría derecho a ser enterrado en el presbiterio. "Item ... se ha de dar entierro a dicho Fundador en mitad de la capilla mayor, con el túmulo y pompa que al dicho Fundador pareciere." 2

Esta cláusula se pudo cumplir hasta fines del siglo xvi o principios del xvir, ya que San Pedro y San Pablo fue dedicado solemnemente en $1603 \mathrm{y}$, para esta fecha, ya estaba el monumento funerario concluido. La importancia que tuvo el monumento nos lo indica el que lo encon. tremos mencionado en los tres grandes cronistas jesuitas: Pérez de Rivas, Florencia y Alegre. El que nos da, sin embargo, una descripción más minuciosa, es el padre Florencia, que parece haberlo tenido a la vista cuando lo describía en esta forma:

"En el funeral de su suegro Alonso de Villaseca, no se mostró heredero ni yerno Agustín Guerrero de Luna sino más que hijo y amigo en la magnificencia y gastos excesivos que hizo. $\mathrm{Y}$ porque se viera que duraba y permanecía en su ánimo la memoria estimable de quien con su hija le había dado tanta riqueza, años después (de su muerte) cuando se acabó la iglesia de San Pedro y San Pablo, le erigió un suntuoso mausoleo. Este es todo de mármol blanco, de obra corintia, con columnas acanaladas que sustentan vistoso remate que lo forman dos roleos que están teniendo un hermoso escudo con sus armas que son: en el cuartel superior derecho un castillo con una estrella de ocho rayos encima de la almena de enmedio; en el cuartel de abajo trece roleos en campo de oro con tres flores de lis y orla colorada. En los dos de la izquierda un águila y una banda negra atravesada de esquina a esquina, con perfiles colorados en campo de oro con su orladura. Sobre el escudo un morrión con su penacho de plumas y un brazo con una espada. Es de advertir que sólo el castillo y banda son los cuarteles de Villaseca y los otros son de los Guerrero, ya que como emparentaron con los de Luna, se mezclaron las divisas de sus armas."

"Estas eran las armas de su profana nobleza. Las de su hidalguía cristiana son las cuatro Virtudes cardinales que se ven en los cuatro nichos de los intercolumnios. Están (además), la Fe y la Esperanza por remate de los roleos y la Caridad debajo del arco redondo que cierra el nicho principal, todas con sus insignias. En este nicho está la estatua, de cuerpo entero, de rodillas, mirando al altar mayor con tal disposición que dicha virtud está como corona sobre su cabeza, porque en realidad fue la Garidad la que coronó sus virtudes."

2 Florencia, P. Francisco de. Historia de la Provincia de la Compañía de Jesus de Nueva España. México, 1694, libro v cap. I. 
"A un lado y a otro de su estatua, están dos cigüeñas de bronce dorado y debajo, sobre la loza de su sepulcro, cuatro leones del mismo metal. Son preseas que dejó vinculadas al mayorazgo espiritual de su fundación y se estima como prendas suyas."

"En la parte alta, sobre el escudo de sus armas, está la Fama sonora voceando con su clarín... las virtudes de tan heroico y magnánimo bienhechor." 3

Permaneció este entierro casi inalterado, pues el padre Alegre en su Historia, lo menciona expresamente diciendo que: “. . . un túmulo de mármol ... con un vistoso arco..." 4 aunque ya no menciona las cigüeñas ni los leones en bronce. Estos, posiblemente estaban en las esquinas de la lápida en actitud de custodiarla, como unos perros en piedra que existieron, hasta hace pocos años, en el atrio del convento de Tepeaca y que también datan del siglo xvi.

Al ser expulsada de México Ia Compañía de Jesús, en 1767, la iglesia de San Pedro y San Pablo quedó fuera del culto, despojada de sus alhajas más preciosas; sus retablos pasaron al Sagrario Metropolitano (hace unos meses a la Catedral, cerrando las naves procesionales), dispersadas sus imágenes y reliquias, habiendo pasado a otras iglesias hasta las vidrieras y las rejas.

Por disposición del arzobispo Lorenzana fueron extraídos los restos de los difuntos que estaban sepultados en la iglesia, capilla de la Purísima y sacristía. La Gazeta de México de 11 de agosto de 1784 informó que los restos de don Alonso de Villaseca fueron trasladados la noche del 20 de julio de dicho año al Convento Grande de San Francisco, "a solicitud de D. Luis María Moreno de Monroy, su descendiente y sucesor en los mayorazgos que fundó...".

La iglesia de San Pedro y San Pablo volvió ocasionalmente al culto, aunque ya privada de todo lo que hacía su riqueza. Entre 1784, año en que fueron trasladados los restos y 1850 en que fue retirada definitivamente del servicio divino, se debe colocar la fecha, que no he podido precisar, en la que el magnífico monumento funerario de don Alonso de Villaseca fue arrancado del presbiterio y colocado en la Parroquia de San Miguel, tapiando, para ponerlo, la puerta lateral.

$\mathrm{Y}$ aquí interviene la feliz casualidad de que antes hablaba y que me permitió adivinar, tras un insulso retablo neoclásico, un monumento renacentista e identificarlo como el sepulcro de Villaseca.

3 op cit., libro v, cap. I.

4 Alegre, P. Francisco Javier. Historia de la Compañia de Jestis en Nueva España. Mexico, 1841. Tomo I, Lib. IV, p. 408. 
DOI: http://dx.doi.org/10.22201/iie.18703068ed 964.33 .777
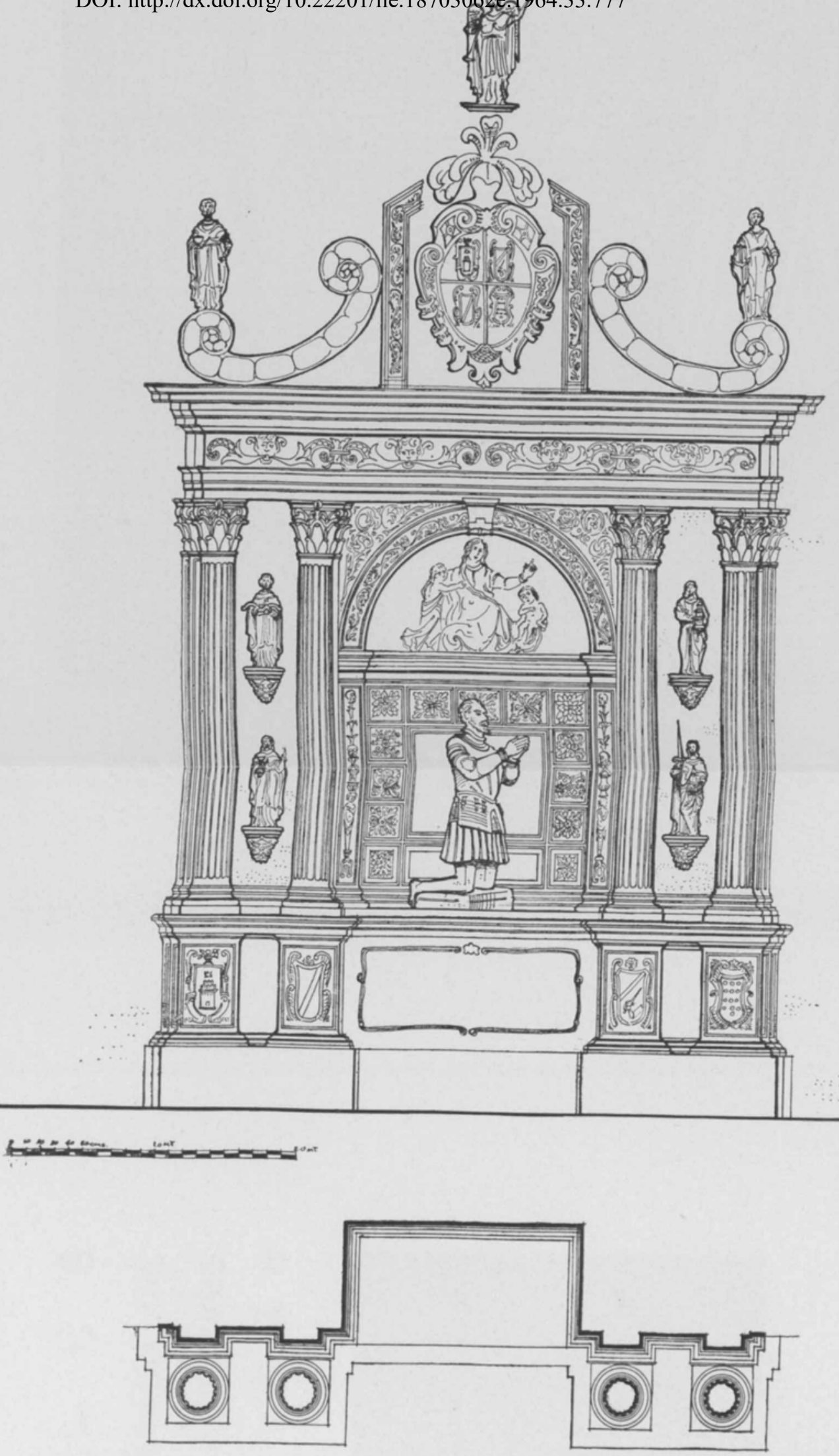

Relevé de Efrain Gasque 
En 1956, al estar haciendo un estudio de las pinturas existentes en la parroquia de San Miguel, pude observar que en el altar dedicado a San Antonio de Padua (el primero entrando a la izquierda, frente a la capilla del Santísimo) el nicho tenía al fondo, un bello bajorrelieve en mármol y los pedestales de las columnas unos escudos nobiliarios. El examen cuidadoso de este monumento me planteó una serie de problemas, ya que por su composición y detalles decorativos parecía una obra renacentista de mediados del siglo xvi. ¿Cómo podía estar en una iglesia, como la de San Miguel, construida de 1692 a 1714? Don Manuel Romero de Terreros, que me hizo el favor de acompañarme alguna vez, tampoco pudo explicar esta anomalía ni identificar los escudos.

No fue sino hasta dos años más tarde, cuando, con motivo de la restau. ración de la Capilla Doméstica de Tepotzotlán, tuve que estudiar en detalle las crónicas de los Jesuitas, y encontré en la del padre Francisco de Florencia la descripción del monumento de Villaseca y se me vino a la memoria el que había estudiado en la Parroquia de San Miguel. Confronté el texto con el retablo y llegué a la conclusión de que lo que tenía delante de mi era, sin lugar a dudas, los restos del magnífico monumento funerario de don Alonso de Villaseca. Veamos ahora lo que queda de él.

Tal como se presenta ante nosotros da la impresión de un altar neoclásico, como tantos otros que existen en México. Sin embargo, si nos acercamos notaremos que está construido en mármol blanco casi todo, incluso las columnas y que sobre esto se le agregó un pesado entablamento y frontón en madera pintada de blanco suprimiendo estos agre. gados, el monumento original queda compuesto por los siguientes elementos: un zócalo moldurado del que se desprenden los pedestales de cuatro columnas corintias, de fuste acanalado. Las columnas enmarcan un gran nicho rehundido. La parte superior está oculta por los agregados neoclásicos.

En la parte de los pedestales hay ocho escudos que corresponden a la descripción de Florencia. Debieron de ser doce, pero están raspados los que correspondían al frente, como también está raspada la cartela o inscripción de la parte central. Los escudos existentes son tres: Uno con trece róleos, dispuestos en cinco filas; el otro con una banda atravesada en la parte superior y un brazo armado blandiendo una espada en el inferior $y$, finalmente, el tercero nos presenta un torreón que recuerda singularmente el rollo de Tepeaca, coronado por esas características almenas que encontramos en todos los monumentos del siglo xvi. Sobre el torreón hay una estrella de ocho picos. 
DOI: http://dx.doi.org/10.22201/iie.18703062e.1964.33.777 
DOI: http://dx.doi.org/10.22201/iie.18703062e.1964.33.777

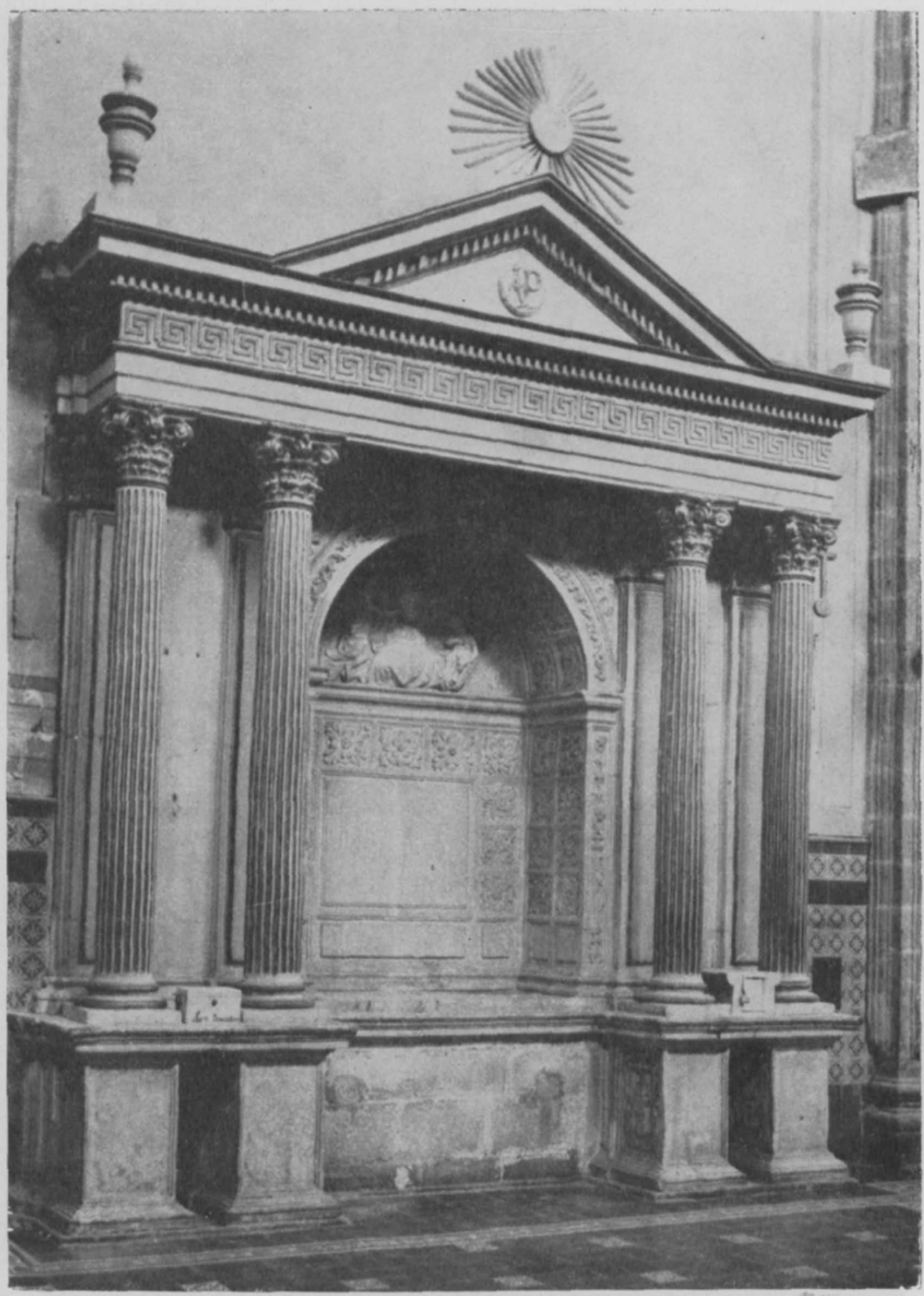

Iglesia de San Miguel. México, D. F. Sepulcro. 
DOI: http://dx.doi.org/10.22201/iie.18703062e.1964.33.777

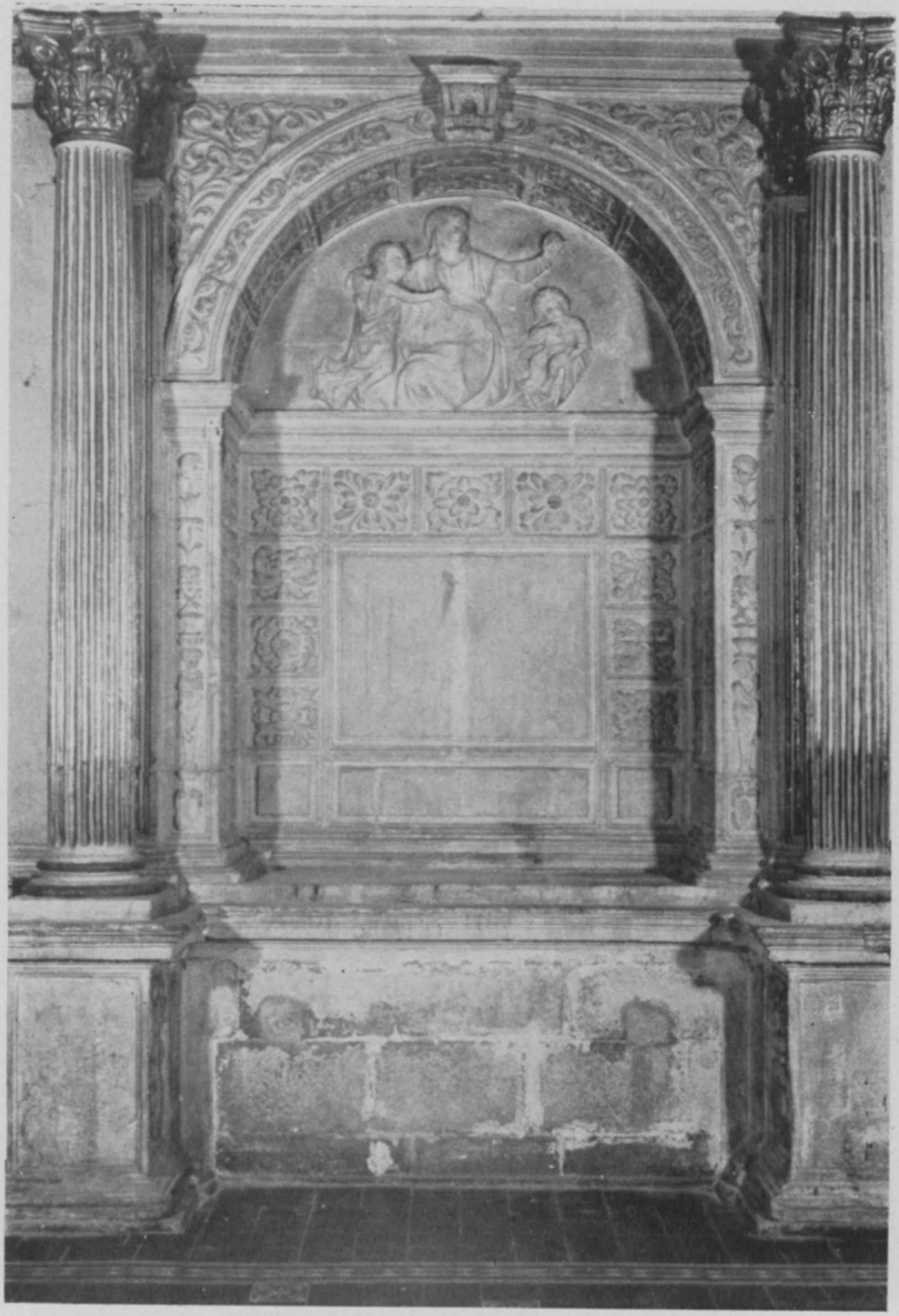

Sepulcro de don Alonso de Villaseca. 


\section{s}

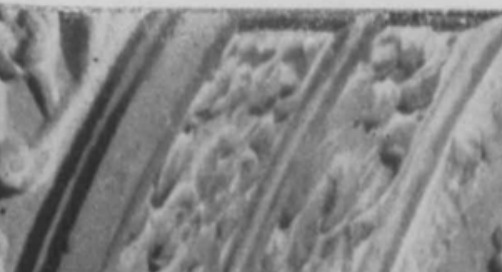

)
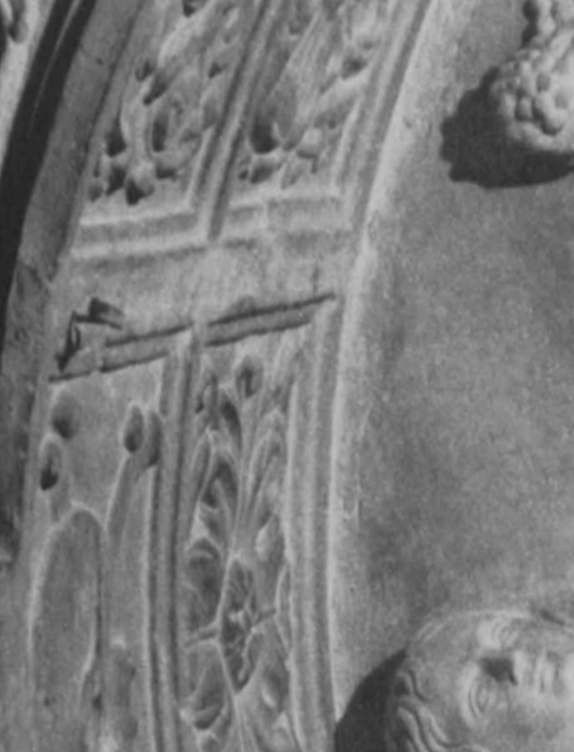

i.

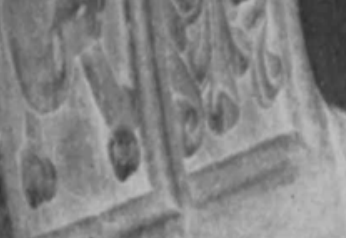

\section{ty}

5 (ख)
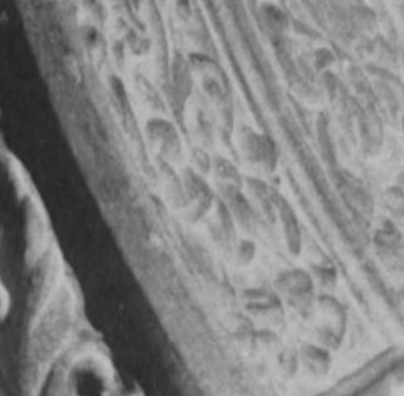

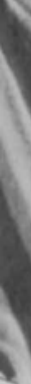
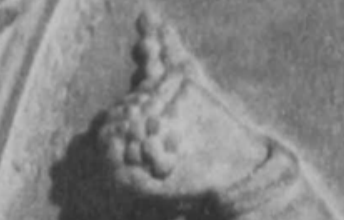
DOI: http://dx.doi.org/10.22201/iie.18703062e.1964.33.777

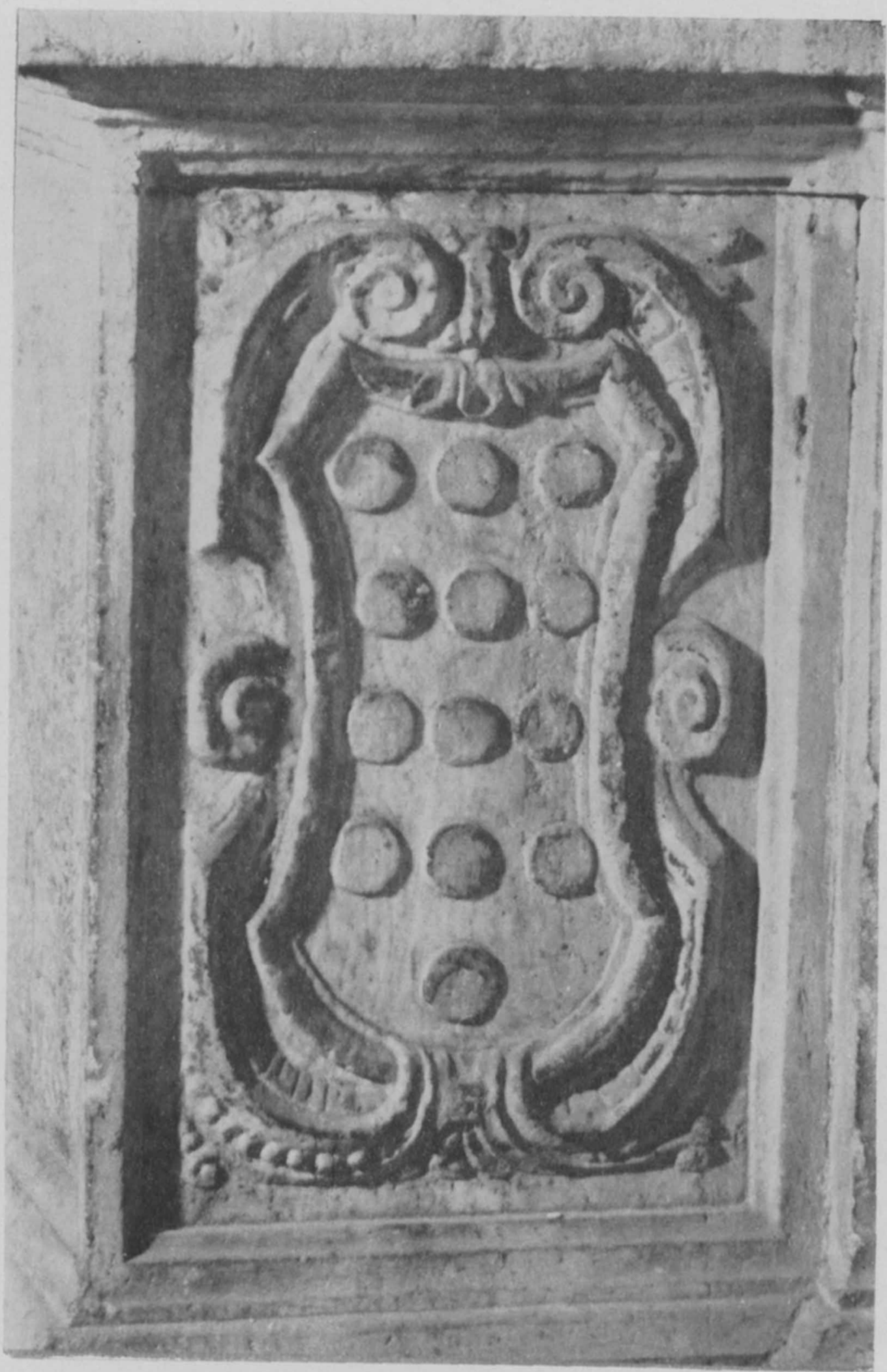

Sepulcro de don Alonso de Villaseca. Escudo. 
DOI: http://dx.doi.org/10.22201/iie.18703062e.1964.33.777

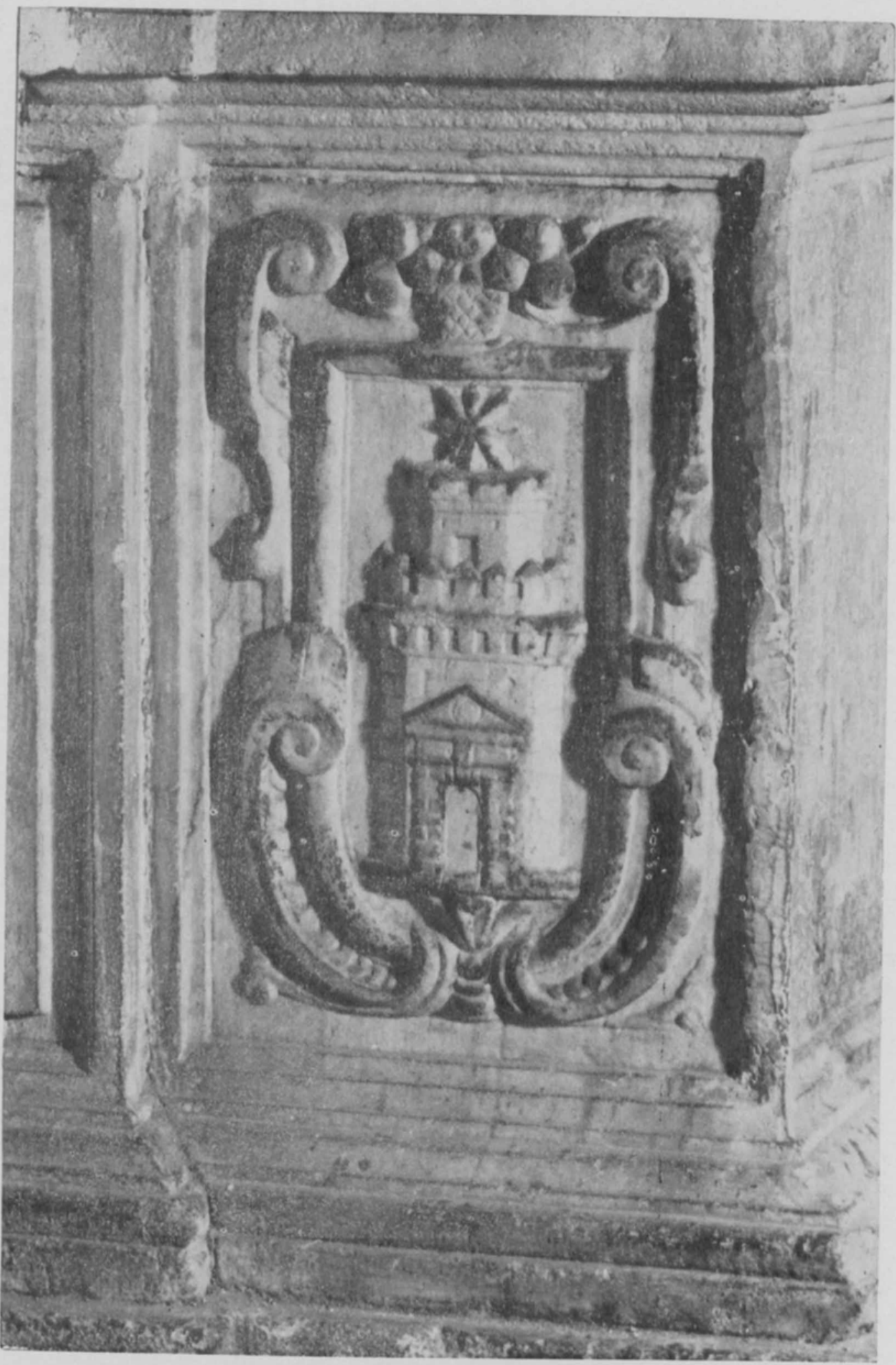

Sepulcro de dö Alonso dè Villaseca.. Escußło. 
DOI: http://dx.doi.org/10.22201/iie.18703062e.1964.33.777

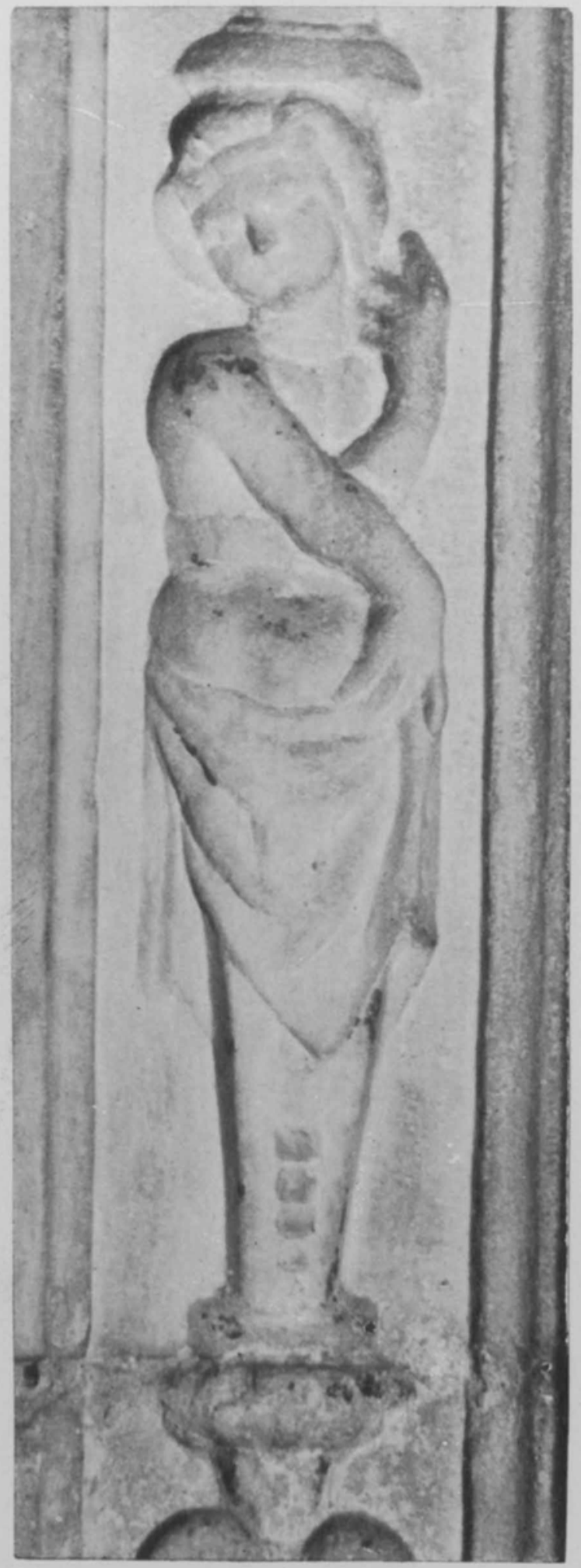

Sepulcro de don Alonso de Villaseca. Detalle. 
Desaparecieron no sólo los escudos del frente sino también las esculturas que estaban en los intercolumnios con las virtudes cardinales. Quedan restos de ellas, incluso se adivina el pedestal que las sostenía. Lo más completo del monumento se conserva en la parte central, en el nicho.

Este "arcosolium" es de excelentes proporciones y debió de albergar con toda amplitud la estatua del orante. Está concebido dentro del más puro renacimiento y las pilastras que lo enmarcan y el intradós del arco se cubren de finísimos grutescos. Son particularmente notables los de las pilastras laterales, adornos entrelazados con calaveras, recordando el destino fúnebre del monumento.

Este mismo motivo del cráneo, admirablemente labrado, lo encontramos en la parte superior. Al fondo, en el luneto, un bellísimo bajorrelieve de la Garidad, representada como una matrona amparando a dos niños, a uno de los cuales le ofrece un ramo de uvas, mientras el otro duerme envuelto en los pliegues de su manto.

La factura de este relieve es extraordinariamente fina, de una calidad que hace pensar, por lo suave del modelado y lo esfumado de los contornos en las obras de Bartolomé Ordóñez. Esta misma mano, de un excelente escultor, educado en las mejores tradiciones del arte italiano, la encontramos en los grutescos de la bóveda, en el friso que corre alrededor del arco y en las enjutas del mismo. Continúa en una parte casi invisible, que lo es el entablamento original, oculto tras el pesado agregado neoclásico. Aquí, con mucha dificultad, se distinguen dos ángeles, espléndidamente trabajados, sosteniendo una cartela.

Todo este trabajo escultórico, por su delicadeza, por su temática ornamental, por el aspecto tan caracteristicamente renacentista que presenta, correspondería más bien a la primera mitad del siglo xvi, a un periodo que se podría situar, en España, entre 1520 y 1535 . Es interesante encontrarlo en la Nueva España a fines del siglo xvi.

Debieron de colaborar, en este monumento, por lo menos dos escultores. Al primero correspondería la parte más delicada, pero hay otra mano, menos hábil y más efectista que busca, ya dentro de las tendencias de la época, un claroscuro más acentuado. A este colaborador corresponderían los grutescos que existen en la parte baja del relieve de la Caridad y los escudos de la parte baja, enmarcados en unas cartelas de un incipiente barroquismo, que ya anuncian las tallas coloniales en madera.

$\mathrm{El}$ orante y las esculturas de los remates debieron ser interesantísimas, pero desgraciadamente han desaparecido. ¿No sería parte del primero una escultura mutilada, en mármol blanco, que procedente de la colec- 
ción Luder y Rule está abandonada en los jardines del Hospital de la Luz?

Pero a pesar de estos faltantes, de la desaparición de gran parte de su decoración, el monumento, tal como se conserva, es importantísimo y no creo que haya dentro del arte colonial hispano-americano del siglo xvi, ninguno que le supere en importancia. El mismo material en que está labrado, mármol blanco de gran finura, le da un lugar de excepción dentro de nuestra escultura colonial. Cuando don Juan Guerrero de Luna habla de los gastos hechos por su padre Agustín Guerrero en favor de la Compañía de Jesús, dice que hay que agregar a las cantidades que recibieron: "De $11 \mathrm{mil}$ a $12 \mathrm{mil}$ pesos de oro que costó el monumento y sepulcro de mi señor abuelo Don Alonso, que lo hizo y costeó mi padre, tal como se ve por sus libros de cuentas..." 5 Este precio, altísimo para una obra de este tipo, nos prueba que no se escatimó nada para hacer este sepulcro el más suntuoso que existió, en su época, en la Nueva España. Ojalá se pudiera encontrar, en los libros de Protocolos, el contrato que seguramente se hizo para esta obra.

Este monumento debe ser conocido y apreciado. Algún día, cuando se vuelva a abrir la puerta lateral que está tapando, se podría trasladar a otro sitio más digno de su categoría.

- Apéndice a la Relación breve de la venida de la Compañia de Jesis a la Nueria España. México, 1945. 